Maurice A. Deane School of Law at Hofstra University Scholarly Commons at Hofstra Law

Hofstra Law Faculty Scholarship

Summer 1970

\title{
Political Power and Legal Legitimacy: A Short History of Political Trials
}

Leon Friedman

Maurice A. Deane School of Law at Hofstra University

Follow this and additional works at: https://scholarlycommons.law.hofstra.edu/faculty_scholarship

\section{Recommended Citation}

Leon Friedman, Political Power and Legal Legitimacy: A Short History of Political Trials, 30 Antioch Review 157 (1970)

Available at: https://scholarlycommons.law.hofstra.edu/faculty_scholarship/780

This Article is brought to you for free and open access by Scholarly Commons at Hofstra Law. It has been accepted for inclusion in Hofstra Law Faculty Scholarship by an authorized administrator of Scholarly Commons at Hofstra Law. For more information, please contact lawcls@hofstra.edu. 


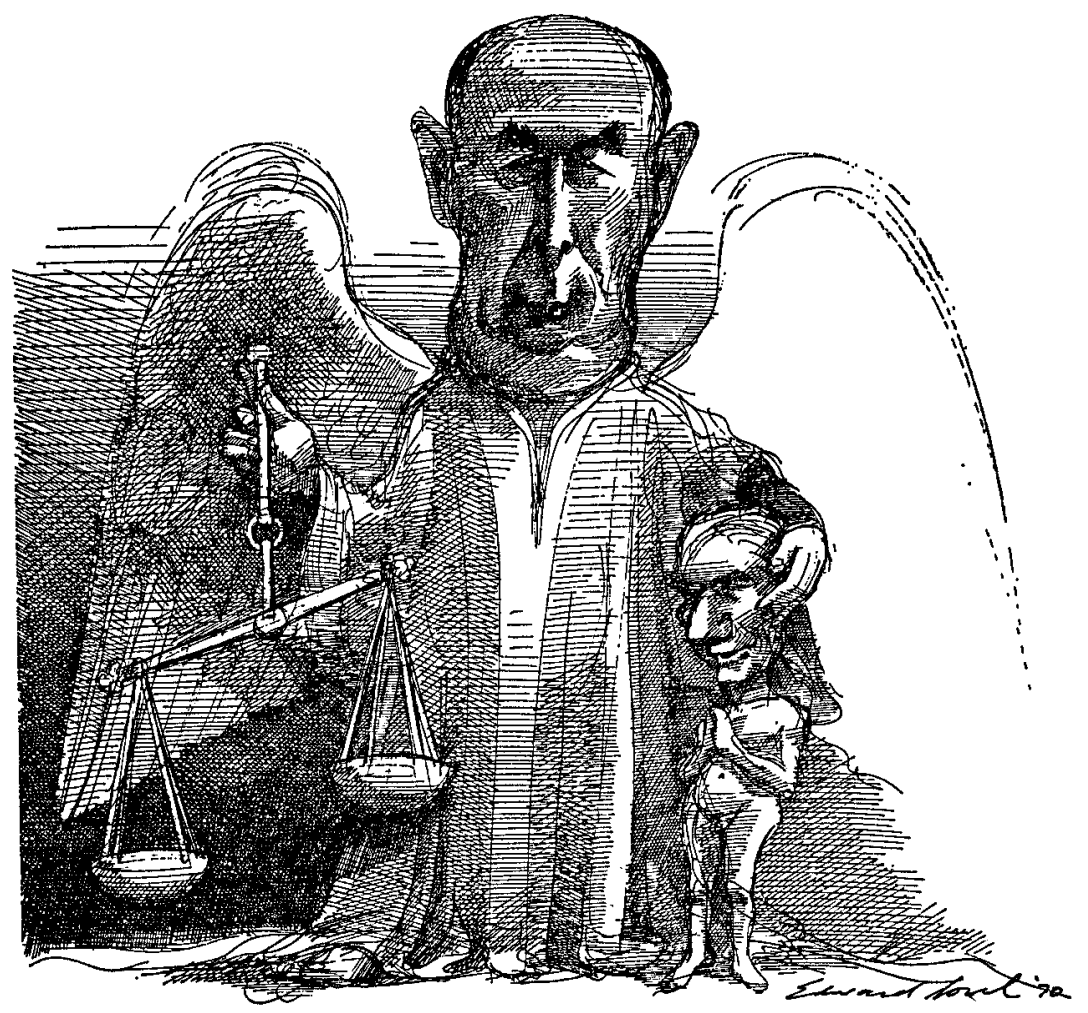



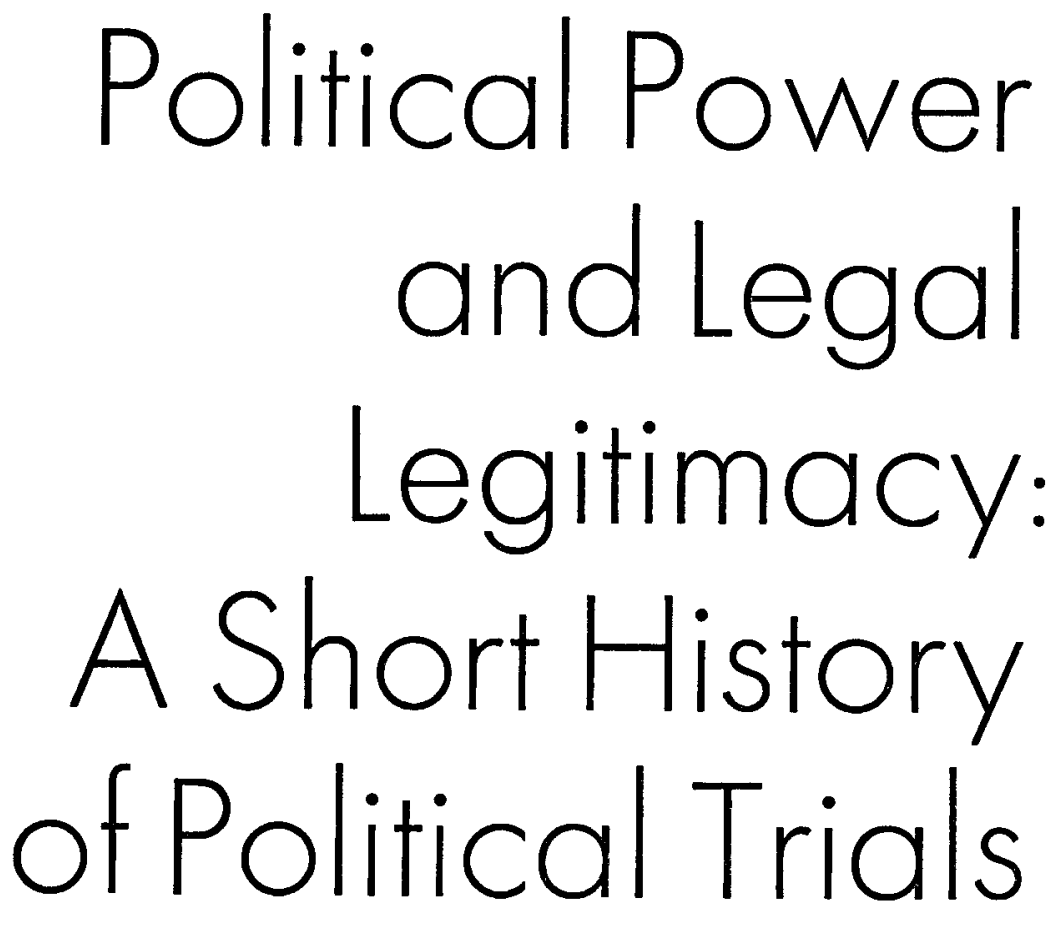

BY LEON FRIEDMAN

A

merica, unlike Europe, has had few dramatic state trials. The treason trial of Aaron Burr and the impeachments of Supreme Court Justice Samuel Chase and President Andrew Johnson were lifeless parodies of the proceedings against Charles I and Warren Hastings in England, or against Louis XVI and Robespierre in France. Nor have we seen the frequent overturn of government which necessitates successor regime trials-cases in which the new rulers try to show the people how corrupt, venal, and criminal their predecessors had been by putting ousted presidents in the dock for embezzlement or treason.

But in other ways the United States has had fully as many political trials as any other nation. In the furious game of politics, the legal system offers a tempting opportunity for those in power to damage enemies, tarnish their image, and isolate them from potential allies by casting them as criminals. And conversely, outgroups may challenge governmental policy in the courts to prove its illegitimacy. Otto Kirchheimer writes in his brilliant book Political Justice: 
... both governments and private groups have tried to enlist the support of the courts for upholding or shifting the balance of political power. With or without disguise, political issues are brought before the courts; they must be faced and weighed on the scales of law, much though the judges may be inclined to evade them. Political trials are inescapable.

Sometimes the term "political trial" is used pejoratively, indicating that the normally neutral legal process is being manipulated for political ends. The defendants usually make the accusation, while the prosecution insists it is merely enforcing the law, i.e. that the usual procedures are being followed. But recently, more and more radical defendants are using the term to describe any court proceeding that gives them the opportunity to make a political point.

Thus, there are three separate types of judicial proceedings which come under the rubric of "political trials": cases which are politically motivated, those that are politically determined, and those which in turn have substantial political consequences.

The first and clearest type is the criminal action initiated by the government against representatives (often the leaders) of its opposition, to suppress their political activities or at the least to shed unfavorable light on their efforts. In the simplest instance, peaceful political activity itself is the basis of the prosecution. In the 1968 Spock trial in Boston, for example, the government charged that antiwar protest actions by a group of East Coast professionals amounted to a conspiracy to violate the draft law, since they encouraged young men to refuse service. In other instances representatives of a political outgroup may be accused of non-political crimes-murder, bank robbery, or perjury-and prosecuted as part of an official campaign of repression or disparagement. Sometimes the crime is an obvious frame-up, as when Hitler accused the Bulgarian Communist, Georgi Dimitrov, of setting the Reichstag fire in 1933 . Or there may be some evidence that a political opponent was involved in illegal activity and the authorities press the case with uncommon vigor (ignoring all evidence to the contrary) to show how criminal their adversaries are. Examples of this kind include the murder trials of Industrial Workers of the World leader Big Bill Haywood in 1907 , of Tom Mooney (a West Coast labor agitator) in 1916 , and of Sacco and Vanzetti in 1921.

A second class of cases commonly considered political trials are those which may not be politically motivated and in which the defendants may not be political activists, but which are substantially affected by politics. The crime may be real and the ordinary legal officers may have initiated the prosecution, but the political currents of the time may be the most significant factor in determining both the guilt of the defendant and his sentence. One historic example is the Andersonville trial of Captain Henry Wirz for 
maltreatment of Union prisoners during the Civil War. A more recent case in point is the trial of the Rosenbergs for espionage during the McCarthy era.

The third category is the converse of the second: ordinary trials which themselves substantially affect the politics of the time, although the crimes at issue may not be political in any sense and the result may not be determined by politics. For example, a leading political figure may be arrested and charged with income tax evasion immediately before an election and thus bring his party to defeat. In one of the most extraordinary episodes in American political history, the Republican Secretary of State of Kentucky, Caleb Powers, was arrested for complicity in the rgoo murder of a Democratic candidate for governor, William Goebel, and his dramatic trial during the election year insured the triumph of the Democrats. Another famous case (involving a civil rather than a criminal proceeding) was the 1889 divorce action brought by Captain William O'Shea against his wife, Kitty, in which he charged her with adultery with Charles Stewart Parnell, the great Irish leader. The scandal destroyed any chance for Irish home rule for decades.

Of course, these categories are not mutually exclusive: a trial may be politically motivated, the result may be determined by the politics of the time, and it may in turn affect the distribution of political power. Law and politics may intermix at any one of these levels and not the others, but the trial is still political in the broadest sense.

\section{THEIR OWN POLITICAL PETARDS}

Paradoxically, the form of political justice that promises the most to the government generally yields the least. Attempts to punish the peaceful political activities of its opponents have generally boomeranged. From the prosecutions under the Alien and Sedition Acts in $1798-99$ to the Chicago Conspiracy trial of $1969-70$, the authorities have succeeded only in increasing the outgroup's political power. The Federalists under John Adams and Timothy Pickering tried to suppress the powerful Democratic-Republican newspapers, such as the Philadelphia Aurora, by indicting their editors under the 1798 Sedition Law. Prosecutions were also commenced against Republican Congressmen and other Federalist critics. The heavy-handed use of the law succeeded in uniting the Jeffersonians for the 1800 election and they swept Adams out of office. (Eight years later the shoe was on the other foot: Jefferson's administration vigorously enforced the Embargo Act in Federalist New England where the law was universally unpopular. Juries refused to return guilty verdicts and the Embargo was practically a dead letter in the Northeast.)

At the time of the Fugitive Slave Law the same pattern repeated itself. The Democratic administration was determined to enforce the $185^{\circ}$ Compromise and deal effectively with those who assisted Negro slaves to escape. Secretary of State Daniel Webster travelled through the North calling 
Abolitionists traitors for blocking enforcement of federal law. After the great New England theologian, Theodore Parker, harangued a Boston crowd about the inhumanity of the Fugitive Law, an attempt was made to rescue a captured black (Anthony Burns) then held in jail. Parker and other speakers were arrested for interfering with the federal law by encouraging the rescuers. Not only was the case eventually dismissed, but the Abolitionists used the opportunity to form a new antislavery party in Massachusetts that eventually captured the state machinery.

Similarly, the 1873 trial of Susan B. Anthony was used for the most effective agitation on women's suffrage up to that point. Fifteen women, led by Miss Anthony, persuaded the voting registrars in Rochester, New York, to let them vote in November, 1872 , claiming that the Fourteenth Amendment passed in 1868 automatically gave women the franchise. (New York allowed only men to vote.) However, a federal law prohibited any person voting without the legal right to do so. On Thanksgiving Day, November 28 , I872, federal marshals served warrants of arrest on each of the ladies who had voted. Trial was set for the summer of 1873 .

Armed with her indictment, Miss Anthony became the star of the women's rights convention in Washington in January of 1873 . In her opening speech she said: "I stand here under indictment for having exercised my right as a citizen to vote at the last election." Before the trial took place, she delivered not less than fifty speeches in upstate New York, pressing her constitutional argument that the Fourteenth Amendment granted suffrage to women. "I not only committed no crime but instead simply exercised my citizen's right, guaranteed to me and all United States citizens by the National Constitution beyond the power of any State to deny."

The trial took place in Canandaigua, New York in June, 1873 . Presiding was a newly-appointed Justice of the United States Supreme Court, Ward Hunt, a protegé and tool of Senator Roscoe Conkling. The government decided to get the trial over with as quickly as possible and not to allow Miss Anthony to use it as a forum for her views. Instead of putting her on the stand, the government read a transcript of her testimony at a preliminary hearing. Hunt would not let her fire her lawyer and conduct the defense herself. Indeed, he would not even permit the defense to present any evidence to answer the government's case. He ruled that the question of whether the Fourteenth Amendment granted women the right to vote was purely a question of law on which he alone could rule. He told the jury:

I have decided ... that under the Fourteenth Amendment, which Miss Anthony claims protects her, she was not protected in a right to vote. And I have decided also that her belief and the advice which she took do not protect her in the act which she committed. If I am right in this, the result must be a verdict on your part of guilty, and I therefore direct that you find a verdict of guilty. 
Miss Anthony's lawyer, Henry R. Selden, objected vigorously. It was unheard of that a judge would direct a guilty verdict without giving the jury a chance to consider the case. Even anti-suffragist newspapers wrote indignant editorials about the procedure. The New York Sun demanded that Hunt be impeached. However, he refused to back down and set the next day for sentencing. In accordance with the usual procedure, he asked Miss Anthony whether she had anything to say before he pronounced sentence. At that point, her first opportunity to speak at her own trial, she rose to her feet and began:

Yes, your Honor, I have many things to say; for in your ordered verdict of guilty, you have trampled under foot every vital principle of our government. My natural rights, my civil rights, my political rights are all alike ignored. Robbed of the fundamental privilege of citizenship, I am degraded from the status of a citizen to that of a subject; and not only myself individually but all of my sex are, by your Honor's verdict, doomed to political subjection under this so-called Republican government.

Hunt tried to stop her, but Miss Anthony continued:

Your denial of my citizen's right to vote is the denial of my right of consent as one of the governed, the denial of my right of representation as one of the taxed, the denial of my right to a trial by jury of my peers as an offender against the law, the denial of my sacred rights to life, liberty, property.

Hunt then fined her $\$ 100$, a lenient sentence under the circumstances. Rather than order her imprisoned until the fine was paid (which would have allowed her to take an immediate appeal) Hunt permitted her to stay at liberty. No effort was ever made to collect the fine, and therefore Hunt's rulings were never questioned by a higher court.

Miss Anthony prepared a full report of the trial, had it printed, and sent out thousands of copies. Women throughout the country sent in money and promises of support to suffragist organizations. More than any other single event in the suffrage drive, the trial politicized and activated thousands of women who then joined in the many state campaigns to change the election laws. The ideas that the leader of the movement could be treated so shabbily by the government, found to be a criminal because she asserted the right to vote under the Fourteenth Amendment, opened many eyes.

\section{POLITICAL PLACEBOS}

The government has been more successful when it has challenged unpopular splinter groups that are no real threat to it. During World War I the government attacked left-wing organizations, such as the I.W.W., the Socialist party, and the Nonpartisan League in North Dakota for opposing the war. 
Hundreds of members were arrested under the Espionage Act of 1917 or the Selective Draft Act. After the war, the notorious Attorney General A. Mitchell Palmer and his colleague Harry $M$. Daugherty engaged in a series of questionable raids on Socialist and Communist headquarters, and deported hundreds of aliens without hearings simply because they belonged to organizations which allegedly supported the dreaded Bolsheviks.

Beginning in 1917 , many states passed criminal syndicalism, sedition, and "anti-Red flag" laws, aimed chiefly at the I.W.W. (whose power had already begun to wane). In $1919-20$, about 1400 persons were arrested under these acts and about 300 imprisoned. From 1919 to 1924 , California, the state most energetic in catching radicals, prosecuted $53 \mathrm{I}$ Wobblies and their allies, convicted 264 and sentenced 128 to prison, including Charlotte Anne Whitney, the niece of Supreme Court Justice Stephen J. Field. The same two witnesses-renegade members of the organization-appeared in almost every case to testify against their former comrades. The state would arrest any defense witnesses who admitted to membership in the I.W.W. It also secured an injunction against the very acts classed as crimes under the law so that a judge could try violations without a jury.

It is hard to see the point of these prosecutions other than to relieve the fears of a population quaking in its boots about the Russian Revolution and Lenin's rise to power. The radicals never commanded any substantial popular support, and the repressive steps taken by the government brought them a measure of sympathy they could never earn on their own. Charles Evans Hughes, a former Supreme Court Justice and rg16 Presidential candidate, condemned the New York Legislature for refusing to seat five Socialist representatives-elect; and a Boston federal judge, George M. Anderson, roundly condemned the government for its illegal raids and alien round-ups.

The Smith Act prosecutions against the Communist party seemed equally unnecessary. By 1949, when the Dennis case was heard, the party had ceased to be a factor of any importance in the United States. Yet to justify its world-wide anti-Communist stance and bolster its domestic political position in the face of Republican right-wing criticism of "softness" on that issue, the government initiated a series of political prosecutions to protect itself against a danger that no longer existed-if it ever did. As Kirchheimer notes: "It is one paradox of political justice that repression is most effective when least necessary-that is, when the regime attacks small, unimportant or transitory minorities-and least likely to be effective in the face of strong, persistent minority opinion and organization."

The most recent politically-motivated indictments against political activity as such were the Spock case in Boston and the Chicago conspiracy trial. The Spock case was the result of a political compromise between the Justice Department and the Selective Service System. In October of 1967 General Lewis Hershey attempted to order priority induction of all draft registrants who turned in their draft cards or sat-in at draft boards as a political protest - an order recently declared unconstitutional by a unanimous 

intellectuals who supported the younger resisters. As a Justice Department prosecutor later admitted, "The prosecution came about as a result of our flap with Hershey about his October 26 letter to the draft boards. The prosecution of these five was thought to be a good way out-it was done to provide a graceful way our for Hershey."

There is no question that the Chicago Conspiracy trial was also politically motivated. Following the disturbances at the Democratic National Convention in August, 1968, Ramsey Clark attempted to have certain members of the Chicago police indicted for interfering with the civil rights of the protesters. However the chief federal judge in Chicago refused to have a grand jury act only against the police and insisted that the demonstrators also be cited. When the Nixon administration took over in January, 1969, the new Justice. Department quickly prepared indictments against the organizers of the Chicago demonstrations and against Bobby Seale, a leader of the Black Panthers, who actually had little to do with the August, 1968, activities. The purpose of the indictments was clear: to show the people that the disturbances were not the result of police riots, as the Walker Commission and virtually every responsible reporter had claimed, but were planned by antiwar organizations, student protesters, Black Panthers and other dissident groups to undermine the political system and to destroy law and order. The political nature of the indictment is revealed by the charges themselves: "It' was a part of said conspiracy that . . . the defendants . . . would organize and attend various meetings, would publish and cause to be published articles, and would make and cause long distance telephone calls for the purpose of encouraging persons to come to Chicago . . . to participate in massive demonstrations." The point of including these acts in the indictment was both to warn other dissenters that peaceful political activity could be the basis of federal charges and to taint the antiwar movement as part of an illegal conspiracy.

The use of conspiracy charges in political cases raises the most serious due process problems. The government can introduce a wide range of evidence, such as statements by alleged co-conspirators which would otherwise not be admissible, and it does not have to show that the defendants succeeded in any way in violating a substantive law. The gravamen of the crime of conspiracy is an agreement to perform an illegal act, whether subsequently accomplished or not, and the agreement can be proved by demonstrating parallel conduct toward an illegal goal. Support of a "co-conspirator's" political position, even applauding one's friends' remarks at public rallies, becomes evidence of an illegal conspiracy, as the government tried to show in the Spock trial. Fortunately, neither the courts nor the juries have accepted the government's broad definition of conspiracy. In the Chicago case the jury acquitted all defendants of conspiracy; and an Oakland jury did the same when California indicted seven leaders of Oakland's Stop the 
Draft Week for organizing protest rallies in October, 1967 , in front of the local induction center. In the Spock case the federal Court of Appeals reversed the conviction. As of this writing, no defendant has been found guilty of conspiracy, arising out of his political activities, in the past five years.

Sometimes the government may attack a single individual whose political stance it finds dangerous. The crusade against Jimmy Hoffa was foreshadowed thirty years ago when the government tried to deport Harry Bridges, the head of the International Longshoremen's Union. Bridges came to the United States from Australia in 1920, and by the middle 1930s he was an important West Coast labor leader with close ties to the Communists. In 1938 the government tried to deport him on the grounds he was then a Communist. A hearing examiner, James Landis of the Harvard Law School, upheld Bridges. Immediately afterwards, the House of Representatives passed a special law ordering Bridges out of the country, but the Senate refused to concur. Congress then, in I940, amended the Alien Registration Law to provide for deportation of any alien who was a member or was affiliated with any subversive organization at any time after entering this country. The sponsor of the law proudly proclaimed it was designed to "get" Bridges. However, the Supreme Court held in I945 that the government had not proved the necessary affiliation to the Communist party to justify deportation of Bridges. (Justice Frank Murphy began his concurring opinion by saying: "The record of this case will stand forever as a monument of man's intolerance of man. Seldom, if ever, in the history of this nation has there been such a concentrated and relentless crusade to deport an individual because he dared to exercise the freedom that belongs to him as a human being and that is guaranteed to him by the Constitution.")

Bridges then applied for citizenship, swearing he had never been a party member. In May of 1949 the government indicted him for taking a false oath and also initiated denaturalization proceedings. He was convicted in $195^{\circ}$ and the government tried to have his bail revoked when the Korean War broke out, claiming Bridges was a menace to national security because of his control of the waterfront workers. However, the Court of Appeals ordered him released. In I953 the Supreme Court reversed his conviction (on the ground that the statute of limitations had run out) and ordered a new denaturalization hearing. In 1955 a federal district judge stated that the testimony of the government witnesses was "Alimsy," "unacceptable," "unsubstantial" and "tinged and colored with discrepancies, animosities, vituperation, hates." Bridges kept his citizenship and continued to live in this country.

Lest anyone think that the Nixon administration's attempt to punish its political enemies is something new, the history of the Bridges case shows that both Roosevelt and Truman were also willing to use the legal process for political ends. Even Frank Murphy, who was so outraged at the Bridges case, had authorized indictments-when he was Attorney General-of 
Spanish Loyalists who were recruiting for the International Brigades. Roosevelt wanted to show Congress that his administration was enforcing the Neutrality Act, and the Loyalists seemed an ideal target to. Murphy.

The point of these examples is that the decision to prosecute political outgroups or their leaders involves complicated political factors that have practically nothing to do with the even-handed upholding of law and order. Prosecutors have such enormous discretion and latitude in initiating any indictment, and the conspiracy doctrine gives them such wide power to prove their case, that they can justify almost any action they wish to take against political fringe groups. The real reason for a prosecution lies in the labyrinth of political calculation that underlies any and all administrations.

\section{UNCOMMON CRIMINALS}

Politics rears its head even when common crimes are involved. Of course no political leader can claim immunity from prosecution for murder or robbery because he is an elected representative or a Black Panther. But too often a political figure is linked to a violent crime on the most tenuous grounds. The stories of the Haymarket bombings, Tom Mooney, and Sacco and Vanzetti have been repeated too often to require retelling. As Max Lerner has commented, "the real crime [of the defendants] was opposition to the dominant economic interest around which the state was organized."

Moreover, even the common crimes laid at the doorstep of political defendants may in fact be the handiwork of agents provacateurs, who instigate the commission of crimes they are supposed to detect and prevent. Many of the Continental police forces carefully developed the art of provoking radicals into outrageous criminal activity. The Tsarist secret police, the Okhrana, infiltrated the Russian revolutionary parties and had two of their best men, Malinovsky and Azev, work with and encourage the most violent factions, even conspiring to commit murder of their own ministers!

Police spies in the United States have had a similar history. A Pinkerton detective, James McParlan, infiltrated the Molly Maguires in the I87os, became a "bodymaster" of one of the lodges, and initiated or participated in the very crimes he later helped to prosecute. Company spies or army agents regularly joined the I.W.W. and led the Wobblies to extravagant actions later put down by the authorities. During World War I, secret army agents spurred a call for a general strike in the Butte, Montana copper mines and prepared leaflets that were clearly in violation of the Espionage Act. After the war, Bureau of Investigation agents from the Justice Department joined the Communists and helped draft propaganda planks that brought the party within the terms of the Deportation Act. A distinguished panel of lawyers, including Zechariah Chafee, Felix Frankfurter and Roscoe Pound issued a pamphlet in I920 entitled Report upon the Illegal Practices of the United States Department of Justice. The report stated that "agents of the Department of Justice have been introduced into radical activities for the purpose of informing on their members or inciting them to activities;
Political

Power

and

Legal

Legitimocy:

A

Short

History

of

Political

Trials 
these agents have even been instructed from Washington to arrange meetings upon certain dates for the express object of facilitating wholesale raids and arrests."

More recently, undercover police agents during the Chicago disturbances were more bloodthirsty and violent in their proposals than any of the actual defendants. One of the four alleged bombers of office buildings and federal offices in New York City-George Demmerle-turned out to be an agent-informer and was the most eager saboteur of the group. And the police have placed many agents among the Black Panthers to encourage them to step beyond the limits of the law. In one recent case in New York, a police agent lured three Panthers into a hotel robbery, supplied maps and an escape car and then arrested the three other participants. A jury could not agree on a verdict, ten members believing that the defendants had been entrapped into committing the crime.*

The use of police spies and informants in narcotics prosecutions is bad enough, but in political cases it raises far more fundamental problems. The English historian, Sir Thomas Erskine May, wrote about another era:

Next in importance to personal freedom is immunity from suspicions and jealous observation. Men may be without restraints upon their liberty; they may pass to and fro at pleasure: but if their steps are tracked by spies and informers, their words noted down for crimination, their associates watched as conspirators-who shall say that they are free? Nothing is more revolting to Englishmen than the espionage which forms part of the administrative system of continental despotisms. It haunts men like an evil genius, chills their gaiety, restrains their wit, casts a shadow over their friendships, and blights their domestic hearth. The freedom of a country may be measured by its immunity from this baleful agency. Rulers who distrust their own people must govern in a spirit of absolutism; and suspected subjects will be ever sensible of their bondage.

\section{THE POLITICAL NEXUS}

Moving to the category of politically determined trials, it should come as no surprise to the legal realists of the I97os that prejudice of all kinds-social, racial, political-has a substantial impact upon the judicial process. Not only does enormous latitude exist at the prosecutorial level, but judges and juries make hundreds of decisions every day that are dictated or affected by their political stance. In the South, every opportunity was taken to exploit the powers of discretion in the legal process in order to perpetuate an oppressive system against the black minority: Southern white judges and

\footnotetext{
- Another case of a police agent-informer involved "Tommy the Traveller," (a spy for an upstate New York sheriff) who allegedly travelled from school to school stirring ip students to commit excesses on campus. His activities came to light in May, 1970 and an investigation was ordered by state authorities.
} 
juries consistently voted to uphold the prevailing system of white supremacy in any case involving black people. (The method was called "underlaw" by a Harvard Law School student, Peter Teachout.) Nor is this unique to the South. A nationwide study of violent crime shows that Negroes are arrested more cavalierly than whites, indicted more often, found guilty in a higher percentage of cases and sentenced to longer terms.*

Members of unpopular political groups have always been subject to the emotional hates and fears of judges and juries. The behavior of Judge Julius Hoffman in the Chicago conspiracy trial was foreshadowed by that of Judge Joseph E. Gary in the Haymarket trials of 1886 and of Webster Thayer during the Sacco-Vanzetti case. During the McCarthy era of the early I950s, judges would regularly rule against supposed Communists on the most tenuous grounds. Charles Whittaker, later a Supreme Court Justice, decided in 1955 while a district court judge, that invoking the Fifth Amendment was adequate cause for dismissing a teacher: ".. the refusal of a teacherin a most intimate position to mould the minds of the youth of the countryto answer to the responsible officials of the school whether he is a member of a found and declared conspiracy by a Godless group to overthrow our Government by force, constitutes 'adequate cause' for the dismissal of a teacher." A Savannah, Georgia judge sentenced a Vietnam draft resister to ten years in jail with these words: "We can't fool around with people like this. We are in a war and a man who is a citizen of this country ought to act as such." A New York City judge sent thirty-five white students to jail for disrupting their school with demands for the admission of one thousand Negroes and Puerto Ricans: "When you decide that you're going to change Brooklyn College on your own ... why shouldn't the kid who needs some money snatch a pocketbook?"

A jury is equally liable to the political pressures of the time. The foreman of the Sacco-Vanzetti jury said to a friend before he was called for duty: "Damn them! They ought to hang them. . . ." One of the Spock trial jurors told Jessica Mitford: "I personally feel the government had a weak case. But if the defendants had been found not guilty-we'd have chaos!" And members of the Chicago jury indicated that their decision was certainly affected by the growing militancy of the antiwar protest movement.

In short, the concept of a politically-insulated prosecutor, a neutral court and jury, and a normal trial is more an ideal than a reality, and it ceases to exist entirely when political outgroups and vociferous dissenters are brought into the judicial system. It is total hypocrisy to attack the Chicago defend-

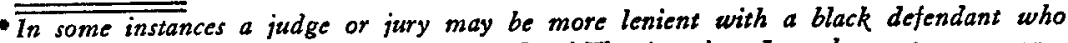
attacks other blacks. In Harry Kalven's study of The American Jury, he quotes an anonymous judge who commented: "Negroes are not held to the same moral responsibility as white people." But the reason for leniency is not sympathy for the black defendant but contempt for the black victim. When a white victim is involved, the jury loses its benign attitude.
}

Political

Power

and

Legal

Legitimacy:

A

Short

History

of

Political

Trials 
ants for bringing politics into their proceeding: it was politics that brought them into the court room. To accuse them of tainting the trial with extraneous political considerations is to swallow the government's whitewash.

\section{CALCULATION AND CONSEQUENCE}

Almost any criminal case can have a political impact. It can remove political opponents altogether (like the Moscow Purge Trials of the 1930s), isolate a particular enemy of the government (like Clemenceau's charges of treason against Joseph Caillaux during World War I) or taint an entire political party (like the Republicans' use of the Alger Hiss case during the $195^{2}$ election). On the simplest day-to-day level, criminal proceedings show the measure of any minority group's political power. It is no accident that blacks seldom won any criminal case in the South or that the poor fare so badly in urban courts today. Criminal trials of any kind against members of a minority group can increase their group's sense of powerlessness and help maintain them in a subservient position.

But the process can work in reverse. By defining the reach and force of an unjust law or governmental policy, a criminal trial can stir outgroups to corrective political action, encourage them to seek and find allies and gain them sympathy with the public at large. Some of history's greatest social and political movements have been seeded by court proceedings: the English Civil War and John Lilburne's case, the American Revolution and the Writs of Assistance case, and more recently, the civil rights drive and the school segregation cases.

What a defendant does in a political trial rests on the same type of calculation that inspired the government to indict him in the first place. He must consider what kind of behavior is most likely to advance his group's political ends. He may come into court defiant and unbending, proclaiming his right to commit the crime. Models for this strategy exist in all countries. When only twenty-six years old, Leon Trotsky was tried for illegal insurrection for his part in the I905 Petrograd uprising and used the opportunity to indict the regime that had put him on trial. Solomon Telririam, a young Armenian, killed Pasha Talaat, the Turkish minister who had been primarily responsible for the Armenian massacre during World War I, and at his murder trial (held in Berlin in 1922) his lawyer exposed the full involvement of the Turkish leaders in the slaughter. Telririam was promptly acquitted. Two Hungarian Jews killed Dr. Rudolf Kastner in Tel Aviv in March 1957 and defended their action by describing the extent of Kastner's collaboration with the Nazis.

More recently, a number of "ultra-resisters" have invaded draft boards throughout the country and destroyed Selective Service records to show their opposition to the Vietnam war. The Catonsville Nine, the Milwaukee Fourteen, the D. C. Nine (who vandalized the Dow Chemical offices in Washington) and fifty other similar defendants used their trials to under- 
score the immorality of the government's policies in Southeast Asia. In the Catonsville case, William Kunstler told the jury that the defendants were morally justified in destroying papers that fed the war machine and that the jury should ignore the judge's instructions and acquit all those on trial. In another case in Chicago the defendants pleaded they were "insane" when they invaded the draft board-totally out of phase with the prevailing principles of this society and incapable of restraining their impulses to stop the war.

Other defendants may feel that the most effective action is to play by the court's rules and to win an acquittal. Even in Nazi Germany, Georgi Dimitrov won the Reichstag fire case and ten years later Leon Blum blocked the efforts of the Vichy government to try him for treason by a brilliant courtroom performance. Both the Oakland Seven and the Dr. Spock group eventually won their cases through traditional legal means. Beating the government at its own game can have wide political consequences, since it confirms the defendants' claim that they were being prosecuted for their political beliefs, thereby tarnishing the legitimacy of the government.

A new pattern has emerged in the Chicago conspiracy case and the Black Panther " $2 \mathrm{I}$ " trial in New York City. The defendants reacted to what they felt were outrageously unfair rulings by the presiding judge (or, in the case of the Panthers, the outrageously high bail imposed on them) and refused to observe the traditional decorum of the courtroom. Abbie Hoffman explained later: ". . . the judicial system plays a role in the war against Vietnam and in the whole system. Every political trial ought to be a direct attack on the judicial system. That is the issue." In the same interview he said: ". . . we tried to explain our case, we tried to destroy the American judicial system, we tried to win the case before the jury, and we tried to win the case before the young people around the world and build a revolutionary movement."

In fact, these goals proved self-contradictory. The brand of confrontation-politics played in Judge Hoffman's courtroom offended the jury as it did the great majority of the country. But on the other hand no other strategy could have attracted the world-wide attention the case received. The Panthers disrupted their trial to show the chasm between the black community and white American justice. (One of the defendants complained when the Prosecutor was called the representative of "The People." "You're not using the word 'People' in the same way that we are using it," he said.)

Each strategy necessarily has its cost and its gains: disruption may offend white middle-class supporters with much needed bail money and may lead to stiffer jail sentences, but it also heartens the hard-core. A legalistic defense may disillusion radical followers, but it might bring about an acquittal. Running away forfeits the educative function that a political trial can serve, but it insures the freedom and continued activity of the defendant. Each choice depends on the legal defenses available, the extent of media coverage and the political pressures of the time.

Political

Power

and

Legal

Legitimacy:

A

Short

History

of

Political

Triais
169

The

Antioch

Review 
Another calculation must be the respect that the majority still holds for the courts. It is an article of faith among lawyers and most laymen that the courts are somehow above the battle, regularly protect minority rights, and strive for impartiality in settling social disputes. The poor have always known this is a myth. While the Supreme Court in recent years has made important adjustments in favor of minority groups, the immediate handling of day-to-day legal problems produced by the disproportionate sharing of political power in our society is still in the hands of a judicial class unsympathetic to innovative political tactics and widespread change. *And the government consistently takes advantage of those prejudices. An outgroup's reaction to this situation cannot be viewed as morally reprehensible. A court, after all, is not a temple. The final guardian of social peace is a pervasive sense of legitimacy which our institutions, including the courts, must earn by a better balancing of political forces than they have achieved in the immediate past.

\section{INVITATION}

\section{BY' LEONARD NATHAN}

We asked the assassin to dinner,

Believing a feast of reasons

Would bring him loving to justice,

But then he looked up with the whites

Of his eyes and softly inquired:

Who provided this meat?

And down the long barrel of silence,

Every knife there glittered. 